\title{
How E-learning Business for Teens Has Evolved in Korea: The Case of MegaStudy
}

\author{
Jiwhan Kim \\ Korea Youth Association for Social Studies \\ Seoul, Korea \\ Seongcheol Kim \\ School of Media and Communication \\ Korea University, Seoul, Korea
}

\begin{abstract}
Since MegaStudy started e-learning business for Korean high school students, the Korean e-learning industry began to expand and steadily gain attention. This paper focused on the analysis of the development of the Korean e-learning business for teens and the growth of MegaStudy. The three institutional mechanisms were used to examine the factors that aided the development of the business. The regulatory mechanism was the government policy to prevent the expansion of the offline private education sector, which greatly aided the growth of the e-learning business. The mimetic mechanism was the notion to mimic the characteristics of the Korean ebusiness initiatives. The normative mechanism involved the widespread social norm suggesting that every student should be given an equal opportunity of private education. This paper also examined the case of MegaStudy as a successful case of the e-learning companies. It analyzed the business model of MegaStudy, which is based on its advantage as the front-runner and its high-quality contents and services.
\end{abstract}

Keywords: MegaStudy, e-learning, e-learning business, Korea, institutionalization, business model

\section{INTRODUCTION}

Education has always been a major issue in the human society. Especially in Korea, the intense competition among students has driven them to turn to private education, and the amount of time and resources consumed for private education has exponentially increased. This rapid increase of private education and a growing number of households unable to manage the high cost called for the emergence of a new form of private education, which turned out to be the e-learning business.

Ever since MegaStudy, a Korean e-learning company, started providing online education services for Korean high school students, the Korean e-learning industry began to expand and steadily gain attention. Following MegaStudy, a lot of other e-learning companies entered the market and by their success firmly established the industry as a profitable blue ocean. However, researchers have not paid much attention to the business potential of e-learning for teens. This paper focuses on the following key research questions:

\footnotetext{
*Corresponding author. E-mail : hiddentrees@korea.ac.kr Manuscript received Dec. 30, 2011 ; accepted Feb.07, 2012
}

(1) What are the basic characteristics of e-learning for teens in Korea?

(2) How has the Korean e-learning business responded to new media such as social networking services and mobile technologies?

(3) What institutional mechanisms were involved in the evolution of the Korean e-learning business?

(4) What business models did contribute to the success of MegaStudy?

To address the questions above, this paper will use the case study approach. Specifically, this study investigates how the three institutional mechanisms, the regulatory/coercive, mimetic/cognitive, and normative mechanisms contributed to the development of the Korean e-learning business. Moreover, it will examine the growth of MegaStudy by analyzing its business model and strategies.

\section{E-LEARNING AND THE E-LEARNING BUSINESS}

\subsection{Basic characteristics of e-learning}

E-learning first made an appearance in the 1990s as the 
development of information technology and the widespread use of the Internet [1]. However, it is not until the early $21^{\text {st }}$ century that e-learning became widely used as a means of private education.

The most prominent feature of e-learning is its accessibility. Korea has the highest Internet usage rate in the world, and that means almost every Korean student can access the Internet. Before the e-learning companies made an appearance, students had to be physically present at private education institutes in order to receive private education. Using e-learning, however, students can get private education without going to private education institutes, which greatly reduces the time consumed during the transit. Moreover, thanks to the widespread use of electronic devices such as PMPs, MP3s, and electronic dictionaries, students can download e-learning contents and listen to the lectures anytime, anywhere. Even recent developments such as smart mobile devices or the social network services provide an access to e-learning.

Another feature of e-learning is its inexpensiveness. The major reason offline private education became such a concern for students, parents, and the government is the high cost. Private education institutes usually charge more than $\$ 100$ a month, and famous lecturers tend to charge as much as they can; some even charge tens or hundreds more times. Also, most of the students attend more than 2 private education institutes, so it is evident that the cost of private education is a burden for Korean families. On the other hand, e-learning is far cheaper compared to offline private education. On EBS (Educational Broadcasting System), the e-learning service started by the government in 2004, students can access all of the lectures and courses for free, and the Gangnam-gu office e-learning service only charges $\$ 30$ for 1 year. Even e-learning enterprises such as MegaStudy charge only a minimum amount of money, which is usually less than $\$ 100$ a month. Since e-learning companies can avoid the big capital and investment needed in offline private education, they can provide their services for a much cheaper price.

Additionally, a wide variety of contents is the $3^{\text {rd }}$ characteristic of e-learning. Students usually learn 1 subject at one private education institute, and since they normally take private education in more than 2 subjects, one student attends about 2 to 3 institutes on average. Private institute classes are generally 2 to 3 hours long, hence this means that students consume most of their time after school on 2 or 3 different private institutes. However, using e-learning services, students can effectively use their time by listening to the courses they need. E-learning companies generally provide a wide variety of courses. For instance, MegaStudy has more than 1,000 different types of courses that can be accessed [2]. By paying less than a half than private institutes, students can use every course the company provides; this wide variety of contents is a major advantage of e-learning over offline private education. Table 1 summarizes and compares the basic characteristics of elearning and offline private education
Table 1. Basic characteristics of e-learning compared to offline private education

\begin{tabular}{|l|l|l|}
\hline Characteristics & \multicolumn{1}{|c|}{ E-learning } & \multicolumn{1}{|c|}{$\begin{array}{c}\text { Offline private } \\
\text { education }\end{array}$} \\
\hline Accessibility & $\begin{array}{l}\text { Students can } \\
\text { use contents } \\
\text { anywhere, } \\
\text { anytime }\end{array}$ & $\begin{array}{l}\text { Students must } \\
\text { physically be present } \\
\text { at private institutions }\end{array}$ \\
\hline $\begin{array}{l}\text { Inexpensive: } \\
\text { less than } \$ 100 \\
\text { a month }\end{array}$ & $\begin{array}{l}\text { Expensive: minimum } \\
\text { \$100 a month (can be } \\
\text { tens to hundreds } \\
\text { more times expensive } \\
\text { depending on } \\
\text { teacher) }\end{array}$ \\
\hline $\begin{array}{l}\text { Variety of } \\
\text { contents }\end{array}$ & $\begin{array}{l}\text { Wide variety of } \\
\text { contents: } \\
\text { hundreds of } \\
\text { different } \\
\text { courses }\end{array}$ & $\begin{array}{l}\text { Generally one subject } \\
\text { at one institute }\end{array}$ \\
\hline
\end{tabular}

\subsection{New opportunities for the e-learning business}

The e-learning business originally was based solely on the Internet. However, the current development of Web 2.0 associated with the widespread use of social networking services and mobile Internet is dramatically changing the structure of the business.

Web 2.0 is enables the users to directly interact with each other or the developer of the original content. In other words, Web 2.0 provided an online space for users to share information and interests actively [3]. If the users were originally passive content receivers, the users of Web 2.0 can be viewed as active content contributors. The most distinctive feature of Web 2.0 is that it is being grafted onto the digital contents industry [4]. The reason this feature is significant is because if it is applied to the e-learning industry, the structure and flow of education would change drastically. When students begin using Web 2.0, they no longer have a passive role as the receiver of information; instead, they can take an active role in the shaping and editing of the educational contents [3]. Many elearning companies are currently paying great attention to this change.

As Web 2.0 emerged, online social networks gained prominence as well. Today social networking services, or SNS, are rapidly increasing and gaining popularity among the users of Web 2.0. Some of the most well-known sites such as Facebook, Twitter, and YouTube are being used by millions of people all over the world. Applying SNS to e-learning is another possible evolution that is being actively discussed. If elearning could be combined with SNS, it could take advantage of the features of SNS such as socialization and sharing of contents. Especially, considering its rapid increase and features that allow users to socialize and discuss, Facebook is thought to have great potential in the field of e-learning [3].

Also, one of the most recent developments in the elearning business is G-learning, which is combining games with e-learning. G-learning is receiving attention from many 
different new-media companies because by applying the aspects of the gaming industry, it could create innovative educational contents.

Another potentially profitable technology that can be applied to e-learning is mobile technology. The current rapid development of mobile Internet, especially recent inventions such as smart phones or tablet PCs continues to suggest new possibilities for e-learning. The most obvious advantage of applying mobile technology to e-learning is that accessing elearning becomes easier. Using smart mobile devices, people will be able to access e-learning anywhere, anytime. The elearning business will actively incorporate the latest mobile technologies and create innovative and effective methods of teaching and learning [5]. Moreover, in the mobile Internet environment based on smart phones, many different contents such as SNS or online games can be combined to create original contents.

\section{THE DEVELOPMENT OF THE KOREAN E- LEARNING BUSINESS FOR TEENS}

\subsection{The institutional theory}

The institutional theory will be used to analyze the development of the Korean e-learning business for teens. In particular, the institutional theory will be used to explain the processes of how the system of the Korean e-learning business has developed, enforced, evolved because the e-learning business is viewed as an institution that is one of the "multifaced, durable social structures, made up of symbolic elements, social activities, and material resources [6]. Institutionalization is the process in which the structures are maintained and reproduced. The institutional theory is based on 3 different mechanisms: the regulatory/coercive, the mimetic/cognitive, and the normative mechanism. The regulatory mechanism is based on political or legislative influences, as well as firms' intentions. The mimetic/cognitive mechanism can be defined as copying other systems' practices [7]. It is often used when the organizations seek a model to rely on. The normative mechanism stems from norms that are prevalent in the environment where the organization belongs. Sometimes the organizations take action not because the pursuit of profit but because the norms require them to do so.

\subsection{Regulatory/coercive mechanism}

The regulatory mechanism of the Korean e-learning business for teens was the government regulation of the rapidly expanding offline private education. EBS e-learning was first introduced as a measure to combat the private education problem in 2004, but its ineffectiveness caused the government to take more powerful measures. One policy the government enacted was to outlaw all private education after 10 P.M. in Seoul and Gyeonggi-do. Since most of the high school students of Korea stay at school until night and then go to private education institutes, the goal of this policy was to make the access of private education physically impossible. Unfortunately, this measure didn't have a great effect on reducing the private education industry, primarily because students still wanted offline private education and institutes formed an educational "black market" by continuing their services secretly. However, the policy unintentionally aided the development of the e-learning business for teens. E-learning is a form of private education but it can't be regulated unless the government supervises every computer; therefore, many students started turning to e-learning. Since students could access e-learning at home whenever they wanted, the regulation of offline private education resulted in an increase in students using e-learning.

\subsection{Mimetic/cognitive mechanism}

The mimetic mechanism was the notion that the Korean elearning business for teens should mimic other online businesses that achieved success. Korea has one of the most advanced IT infrastructures in the world. This enabled Korean online businesses to provide originally offline services online. For instance, businesses such as online newspapers, online games, e-banking, and online shopping all were usually offline businesses but thanks to the advanced IT infrastructures they could provide online services. Also, since the introduction of the e-government, even public grievance services are provided online. This online environment was one of the main factors that inspired the private education industry to begin online services. Learning from the previous successful online businesses, the Korean private education industry started adapting key features from them and as a result could rapidly solidify its status.

\subsection{Normative mechanism}

The normative mechanism came from the prevalent norm that students must have an alternative way of private education that is cheap and accessible, especially rural students or students that don't have access to private education institutes. A majority of the Korean teenagers in Seoul are receiving regular offline private education at private education institutes. However, private education is far from cheap because the institutes are basically companies that pursue profit. Moreover, the intense competition among the students encouraged them to resort to private education institutes as a means to become better than others. Although private education seems almost necessary for Korean students, some cannot afford the expensive cost. From this problematic situation the norm that students must have an alternative way to get private education emerged, and the norm encouraged the development of elearning as a substitute for the expensive offline private education. E-learning could be a perfect alternative for the students who couldn't afford expensive private education mainly because of its inexpensiveness. Additionally, thanks to the accessibility of e-learning students could receive the same kind of up-to-date education on a nationwide scale. Moreover, the wide variety of online contents provided for the students 
granted them a way to keep up with those who receive expensive private education. Table 2 summarizes the three institutional mechanisms for the development of e-learning business for teens in Korea.

Table 2. The three institutional mechanisms for the development of e-learning

\begin{tabular}{|c|c|c|}
\hline Mechanism & Form & Specific function \\
\hline $\begin{array}{l}\text { Regulatory/ } \\
\text { coercive }\end{array}$ & $\begin{array}{l}\text { Government } \\
\text { regulations }\end{array}$ & $\begin{array}{l}\text { Aid development of e- } \\
\text { learning business for } \\
\text { teens by regulating } \\
\text { offline private } \\
\text { education }\end{array}$ \\
\hline $\begin{array}{l}\text { Mimetic/ } \\
\text { cognitive }\end{array}$ & $\begin{array}{l}\text { Notion that the } \\
\text { business should } \\
\text { mimic other } \\
\text { online businesses } \\
\text { that achieved } \\
\text { success }\end{array}$ & $\begin{array}{l}\text { Actively took } \\
\text { advantage of the IT } \\
\text { infrastructures } \\
\text { Adapting key features } \\
\text { from other online } \\
\text { businesses }\end{array}$ \\
\hline Normative & $\begin{array}{l}\text { Norm that } \\
\text { students must } \\
\text { have an } \\
\text { alternative way of } \\
\text { private education }\end{array}$ & $\begin{array}{l}\text { Companies such as } \\
\text { MegaStudy viewed as } \\
\text { adequate alternative }\end{array}$ \\
\hline
\end{tabular}

\section{THE CASE OF MEGASTUDY}

\subsection{The company overview}

MegaStudy is a Korean e-learning company that was founded in 2000. It runs 2 different services: MegaStudy, which provides high school education, and Mbest, which provides elementary and middle school education. Both services are currently most influential in the respective industries; a major reason why MegaStudy is regarded as the most successful Korean e-learning enterprise [8]. Before the appearance of MegaStudy, the traditional education companies of Korea focused on offline, face-to-face education. However, MegaStudy established an innovative model for the e-learning business by focusing solely on online education from the beginning. The company went public on the KOSDAQ in 2004, and ever since it has been expanding rapidly. In 2009, its turnovers amount to 238.3 million dollars, while its business profits reached 84.7 million dollars [9]. Table 3 shows the yearly growth of MegaStudy.

The success of MegaStudy is significant because it achieved its results while competing with EBS, the e-learning service founded by the government in 2004. EBS e-learning was first founded in 2004 as a government policy to incorporate private education into public education and reduce the spending on private education. The government expected the policy to be a breakthrough in social integration and educational welfare by providing an equal opportunity of education to rural students and students of low socio-economic status [10]. The e-learning policy through EBS seemed to achieve the goal at first, since students could easily use the service without charge. However, the non-profit e-learning service turned out to be an ineffective measure to combat the rapidly expanding offline private education market. One reason was because EBS couldn't provide the students high quality contents. When the offline private education industry invested enormous amounts of money on the development of new educational contents, EBS failed to match the quality of the offline education. On the other hand, MegaStudy provided high-quality contents while keeping the price cheap and this difference led to the success of it

Table 3. Yearly Growth of MegaStudy

\begin{tabular}{|c|c|c|c|c|c|c|c|}
\hline Year & $\mathbf{2 0 0 4}$ & $\mathbf{2 0 0 5}$ & $\mathbf{2 0 0 6}$ & $\mathbf{2 0 0 7}$ & $\mathbf{2 0 0 8}$ & $\mathbf{2 0 0 9}$ & $\mathbf{2 0 1 0}$ \\
\hline $\begin{array}{c}\text { Online } \\
\text { sales } \\
\text { (billion } \\
\text { won) }\end{array}$ & 356 & 435 & 561 & 73.8 & 91.2 & 109.2 & 103.5 \\
\hline $\begin{array}{c}\text { Subscriber } \\
\text { s } \\
\text { (thousand) }\end{array}$ & 850 & 1,150 & 1,480 & 1,799 & 2,123 & 2,498 & 2,799 \\
\hline $\begin{array}{c}\text { Paid } \\
\text { subscribers } \\
\text { (thousand) }\end{array}$ & 190 & 220 & 254 & 310 & 351 & 396 & 375 \\
\hline $\begin{array}{c}\text { Number of } \\
\text { bought } \\
\text { lectures } \\
\text { thousand) }\end{array}$ & 795 & 895 & 1,045 & 1,242 & 1,414 & 1,631 & 1,466 \\
$\begin{array}{c}\text { subscriber } \\
\text { thousand } \\
\text { won) } \\
\text { Sales paid }\end{array}$ & 187 & 197 & 221 & 238 & 260 & 276 & 276 \\
\hline
\end{tabular}

The key strategy that led MegaStudy to such an enormous success was targeting determined students preparing for college and providing them with online video lectures of famous lecturers. Son Joo-Eun, the CEO of MegaStudy, was a lecturer himself before he founded MegaStudy, so he foresaw the potential of the e-learning industry. After founding MegaStudy, he used his connections to recruit high-quality lecturers. Moreover, Son Song-Eun, the younger brother of the CEO, was a former engineer, and due to his experience and expertise MegaStudy could provide high quality streaming services. Currently MegaStudy is outsourcing the management of video traffic [11].

\subsection{The Business model of MegaStudy}

A company's business model is the base of the company's strategies to create, deliver, and capture value. It has been popular since the venture businesses began to emerge in the 1990s [12]. According to Johnson, Christensen and Kagermann [13], a business model consists of 4 different dimensions: customer value proposition, profit formula, key resources, and 
key processes. Customer value proposition means the company sells not only products but also values through the products and services they sell. Profit formula means the outline of how the company creates values for itself while it provides values to consumers. Also, the key resources are the components that can produce values for the company and the consumers. Finally, the key processes are the reoccurring enterprises of the company, such as training, development, manufacturing, budgeting, and sales and service.

In the case of MegaStudy, the customer value proposition was the high quality contents, convenience, and the low price. Firstly, MegaStudy provided high quality educational contents for the Korean students who needed private education by recruiting famous and skillful lecturers. Also, the Internet-based structure of MegaStudy enabled consumers to access the contents conveniently, compared to other private educational institutes, which the students had to physically attend. Finally, MegaStudy sold its contents at a significantly lower price than competing private education companies.

The profit formulas of MegaStudy were the low cost (specifically, zero marginal cost) and the subscription-fee from its large customer base. MegaStudy had an advantage over competitors because unlike private education institutes, it could provide contents without marginal cost. Before MegaStudy, offline private institutes had to give lectures every time a new consumer came. On the other hand, MegaStudy could make their products only once and sell them no matter how many customers there were. This means that there was no marginal cost for MegaStudy, and this became one of its most important profit formulas. Another profit formula was the subscriptionfee. The subscription-fee from large customer base acted as a main profit formula for MegaStudy.

The key resources of MegaStudy were the CEO's reputation, the first mover advantage, and qualified lecturers. Son Joo-Eun, the CEO of MegaStudy, used to be one of the most famous lecturers in the private education sector before he founded MegaStudy. His reputation as a former famous lecturer gave credence to the company and as a result attracted consumers. Also, MegaStudy had the first mover advantage. Because it was the first company to start e-learning in the private education industry, it could fully exploit the advantages of a first mover. The qualified lecturers are another key resource of MegaStudy. As Son started the company, he used his information and connections to recruit the most skillful lecturers in the private education industry. These lecturers naturally led to a production of high quality educational contents, and at the same time lifted the reputation of MegaStudy.

The key processes of MegaStudy were the convenient online delivery and taking advantage of mobile devices. MegaStudy provided various services that help consumers to effectively access the contents. One is the 'power lecture search service.' It enabled consumers to search the lectures they need from the numerous different ones that are present. The 'New Saeng Saeng Player' is a video player that allowed the student to post questions about the lectures while listening to them. Finally, the 'multimedia reply system' enabled the lecturers to easily upload their replies to the questions of the students [11].
Additionally, MegaStudy took full advantage of mobile devices. The educational contents could be downloaded into more than one type of PMP, which made it more convenient for the student to access the contents where and when he/she wanted. Table 4 summarizes the business model of MegaStudy.

Table 4. MegaStudy’s business model

\begin{tabular}{|c|c|}
\hline Business model & Success factors \\
\hline $\begin{array}{l}\text { Customer value } \\
\text { proposition }\end{array}$ & $\begin{array}{l}\text { - High quality contents } \\
\text { - Convenience } \\
\text { - Low price }\end{array}$ \\
\hline Profit formula & $\begin{array}{l}\text { - Low costs, in particular zero } \\
\text { marginal cost } \\
\text { - Subscription-fee (from large } \\
\text { customer base) }\end{array}$ \\
\hline Key resources & $\begin{array}{l}\text { - CEO’s reputation } \\
\text { - First mover advantage } \\
\text { - Qualified lecturers }\end{array}$ \\
\hline Key processes & $\begin{array}{l}\text { - Convenient online delivery } \\
\text { - Taking advantage of mobile } \\
\text { devices }\end{array}$ \\
\hline
\end{tabular}

\section{CONCLUSION}

This paper focused on the tracing the development of the Korean e-learning business for teens and the growth of MegaStudy. The institutional theory was used to examine the factors that aided the development of the business. The regulatory mechanism was the government policy to prevent the expansion of the offline private education sector, which greatly aided the growth of the e-learning business for teens. The mimetic mechanism was the notion to mimic the characteristics of the Korean e-business initiatives. The normative mechanism involved the widespread social norm suggesting that students should be given an equal opportunity of private education.

This paper examined the case of MegaStudy as a successful case of the e-learning companies. It also analyzed the business model of MegaStudy, which is based on its advantage as the front-runner and its high-quality contents and services.

In conclusion, this paper contributes to the analysis of the growth of the Korean e-learning business for teens by using the institutional theory as a basis to identify the key factors that initiated the development of the business. Additionally, it contributes to the analysis of the growth of MegaStudy by identifying its business model.

Nonetheless, this paper has limitations. Primarily, this study is limited to a single case study. Future studies may replicate this study in different countries. Also, this study lacks primary data, so it definitely has space for improvement. Future studies should recognize and attempt to overcome these limitations.

\section{REFERENCES}

[1] Kim, B., Kim, S., Kim, J. “Cost-Effectiveness Analysis on 
On-line and Off-line Extra Curricula Education”, Journal of Fisheries and Marine Sciences Education, Vol. 21, No. 2, pp.199 212, 2009

[2] Lee, Y., Moon, Y., Kim, H., Kim, J. "Environment and Achievement Analysis on Online Public Educational Sites and Online Private Educational Sites”, Korea Contents Association Conference Collection of Dissertations, Vol. 2, No. 1, pp.115 118, 2008

[3] Rodrigues, J., Sabino, F., Zhou, L. "Enhancing e-learning experience with online social networks", IET Communications, Vol. 5, No. 8, pp.1147-1154, 2010

[4] Choi, Y., Shin, S., Kwon, Y., Choi, M. "International standardization of e-learning and future challenges”, Journal of Korean Institute of Information Scientists and Engineers, Vol. 27, No. 7, pp.70 77, 2009

[5] Park, Y. “A Pedagogical Framework for Mobile Learning: Categorizing Educational Applications of Mobile Technologies into Four Types”, International Review of Research in Open and Distance Learning, Vol. 12, No. 2, pp.78 102, 2011

[6] Scott, R.W. Institutions and Organizations, London, Sage Publications, 2001

[7] DiMaggio, P.J., and Powel, W.W. "The iron cage revisited: Institutional isomorphism and collective rationality in organizational fields", American Sociological Review, Vol. 48, No. 2, pp.147-160, 1983

[8] http://blog.naver.com/mrikor/120133438710

[9] http://blog.naver.com/krev/140135566423

[10] Lim, K., Jeoung, Y. "Understanding Major Factors in Taking Internet based Lectures for the National College Entrance Exam according to Academic Performances by Case Studies”, Journal of Korea Contents Association, Vol. 10, No. 12, pp.477 491, 2010

[11] Na, G. "Cases of High School E-learning - MegaStudy”, E-learning Research, Vol. 3, No. 1, pp.152-162, 2004

[12] Kim, S. "New media venture's business models and performance in the foreign markets”, Korean Journal of Broadcasting and Telecommunication Studies, Vol. 24, No. 2, pp.42 69, 2010

[13] Johnson, M. W., Christensen, C. M., \& Kagermann, H. "Reinventing your business model". Harvard Business Review, pp.50 59, December 2008

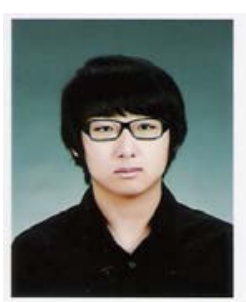

\section{Jiwhan Kim}

$\mathrm{He}$ is the president of Korea Youth Association for Social Studies. He recently graduated Hanyoung Foreign Language High School, Korea. His main research interests include cultural industries such as online gaming, Korean blockbuster movies and e-learning.

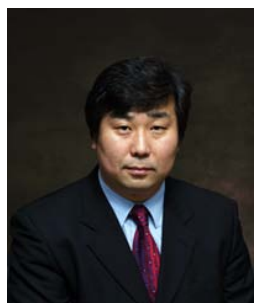

\section{Seongcheol Kim}

$\mathrm{He}$ is a professor in the School of Media and Communication at Korea University. He received his BBA and MBA from Seoul National University and an MA and Ph.D. in Telecommunication from Michigan State University. His research interests include media management and new media business. 